\title{
COMPARATIVE OF FUNGICIDAL EFFICACY AGAINST YELLOW RUST DISEASE IN WHEAT PLANTS IN COMPATIBILITY WITH SOME BIOCHEMICAL ALTERATIONS
}

\author{
M. A. $\operatorname{Gad}^{(1)^{*}}$, Kh. Y. Abdel-Halim(2), Fayza A. Seddik(3) \\ and Hanim M. A. Soliman ${ }^{(3)}$ \\ (1) Wheat Diseases Research Department, Plant Pathology Research Institute, Agriculture \\ Research Center, Egypt \\ (2) Mammalian \& Aquatic Toxicology Department, Central Agricultural Pesticides \\ Laboratory (CAPL), ARC, Dokki, Giza, Egypt \\ (3) Pesticide Residues \& Environmental Pollution Department, Central Agricultural \\ Pesticides Laboratory (CAPL), ARC, Dokki, Giza, Egypt \\ *E-mail: mohamedabo2002@yahoo.com
}

Received: Jan. 23, 2019

Accepted: Dec. 15, 2019

ABSTRACT: Yellow rust of wheat caused by Puccinia striiformis is a destructive disease of wheat. It is present in almost all the wheat growing areas of the world and is a formidable threat to wheat production. The use of chemical fungicides to control plant diseases is an integral component of crop management but should be safety to humans and the environment. Controlling yellow rust disease of wheat by using eight fungicides (Tilt $^{\circledR}$, Fungshow $^{\circledR}$, Abatchi $^{\circledR}$, Crwan $^{\circledR}$, Sumi- ${ }^{\circledR}$, Punch $^{\circledR}$, Emnent $^{\circledR}$ and Meanar $\left.{ }^{\circledR}\right)$ in wheat spray treatments was studied. Residue analysis of such fungicides in grain and straw of wheat after harvest was carried out. The present investigations were carried out in two different locations during the year of 2017/18 growing season and the results of tested fungicides revealed that minimum disease severity of $1.67 \%$ was recorded with Tilt $^{\circledR} 25 \%$ EC. This treatment gave a disease control of $98.07 \%$, thus increasing the grain yield and 1000 kernel weight by 29.92 and $73.61 \%$, respectively. It was followed by a disease control of $96.91 \%$ achieved with Crwan ${ }^{\circledR} 25 \%$ EC which gave an increase of 24.39 and $69.34 \%$ in grain yield and kernel weight, respectively. The analysis of total protein and carbohydrates in grains and straw samples of treated plants shown significant differences within all treatments. Data indicated the residue analysis of fungicides in grain and wheat straw exceeded the allowable maximum residue limits (MRLs) value when using fungicides as spray treatment comparing the MRLs on international authorities.

Key words: Wheat, Yellow rust, Puccinia striiformis, Disease control, Fungicide residues.

\section{INTRODUCTION}

Bread wheat (Triticum aestivum L.) is one of the most important cereal crops and consumed food crops in the world. The high starch content in the grain (60$70 \%$ ) is considered the main source of calories for the human diet (Shewry, 2009). It has an important element in agricultural economy for many countries around the world. It is planted in the largest areas followed by maize, barley and sorghum (FAO, 2009). Yearly, wheat

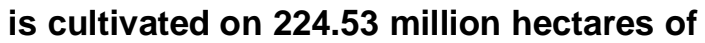
land, yielding for $\mathbf{6 7 2 . 2}$ million tons in the world (USDA, 2010). According to this report the world average wheat production is 2.99 tons/ha. The production of wheat is effected by various biotic and abiotic agents. Among the biotic agents, wheat rust diseases are causes severe losses in grain yield of wheat all over the world. Yellow rust of 
wheat caused by Puccinia striiformis $f$. sp. tritici is posing a potential threat to worldwide wheat production owing to their wide distribution (Chen, 2005). The disease can cause huge losses in grain yields due to reduced size and number of kernels (Weise, 1987). Murray et al. (1995) found that wheat stripe rust reduced the grain yield with $84 \%$, kernel mass with $43 \%$ and kernel number with $72 \%$. Yellow rust can cause $\mathbf{1 0 0} \%$ yield losses in case of susceptible varieties if infection started very early and the disease continues to develop during growing season (Afzal et al. 2007). Chen (2005) found that depending upon the susceptibility of variety, earliness of infection, rate of disease progress and duration of disease, the yield losses caused by yellow rust ranges between 10-70\%. Hasan et al. (2016) and Gebril et al. (2018) reported that wheat yellow rust disease have affected on grain yield of some Egyptian wheat cultivars and also observed negative correlation between disease severity and yield components.

The use of synthetic compounds to control plant diseases dates back to the $19^{\text {th }}$ century, when in 1807, Prévost demonstrated the control of wheat bunt (Tilletia caries) by applying copper sulphate (Russell 2005). The control of stripe rust is very crucial for the global food security. Line (2002) reported that Triadimefon has been used as a foliar fungicide to control yellow rust disease which prevented multi-million dollar losses. Different fungicides like Tilt $^{\circledR}$, Quadris $^{\circledR}$, Stratego ${ }^{\circledR}$, Quilt $^{\circledR}$ etc. have been registered for controlling of yellow rust of wheat worldwide (Chen 2007). ViljanenRollinson et al. (2002) reported that the efficacy of a fungicide depends partly on the growth stage of the crop and disease severity during application. In the view of these concepts, the present study was conducted with the following objectives; (1) to compare the efficacy of different fungicides against stripe rust on wheat plants. (2) to detect the residue levels in grains and straw of wheat crop in compatibility with some biochemical alterations.

\section{MATERIALS AND METHODS}

\section{Experimental design and disease assessment:}

Bread wheat cultivar Sids 12, highly susceptible to yellow rust disease and planted at two locations; Gemmeiza Agricultural Research Station, ElGharbiya Governorate and Itay El-Baroud Agricultural Research Station, El-Behira Governorate. Present investigations were carried out during 2017/18 growing season to control yellow rust disease of wheat caused by Puccinia striiformis. The trial was sown in $4 \times 3 \mathrm{~m}$ plots using the variety Sids 12 in a Randomized Complete Block Design with three replicates for each treatment. Proper fertilizer application and control of insect-pests was followed. Highly susceptible cultivar Morocco was sown on the border rows of the experimental area for the early development and spread of disease. It was artificially inoculated during early January to create stripe rust epidemics. Eight fungicides viz. Tilt $^{\circledR} \quad 25 \%$ EC (Propiconazole), Fungshow $^{\circledR}$ 12.5\% WP (Diniconazole), Abatchi $\quad$ Akonazole $^{\circledR} \quad 25 \% \quad$ EC (Propiconazole), $\quad$ Crwan $^{\circledR} \quad 25 \% \quad$ EC (Propiconazole), $\quad$ Sumi- $^{\circledR} \quad 5 \% \quad$ EC (Diniconazole), $\quad$ Punch $^{\circledR} \quad 40 \%$ EC (Flusilazole), Emnent $^{\circledR} \quad 12.5 \quad \mathrm{EW}$ (Tetraconazole), Meanar ${ }^{\circledR} \quad 41 \%$ EC (Cyproconazole + Propiconazole) were used. The fungicides should be sprayed when leaves showed the symptoms of yellow rust and applied twice at 10 days interval (Bal, 2014). Rust severity was determined according to modified Cobb's scale (Peterson et al. 1948). Total grain yield (Ardab/Feddan) and thousand kernel weight were also recorded. 


\section{Analytical procedures}

Both grains and straw were grinded until fine powder. Then, $5 \mathrm{~g}$ of each was placed into $50 \mathrm{ml}$ polyethylene tube and mixed with $15 \mathrm{ml}$ of acidic acetonitrile. After that, $2 \mathrm{~g}$ of magnesium sulphate and $0.25 \mathrm{~g}$ of sodium chloride were added, shaken vigorously for 15 minutes and then centrifuged for 10 minutes at $4000 \mathrm{rpm}$. $1 \mathrm{ml}$ of supernatant was transferred into 15-ml centrifuge tube containing $100 \mathrm{mg}$ PSA and $600 \mathrm{mg}$ of magnesium sulphate. The extract was processed as described above. The supernatant was filtered through a $0.2 \mu \mathrm{m}$ PTEF filter (Millipore, USA) (Jiang et al. 2009).

Compounds; diniconazole, propiconazole, tetraconazole and cyproconazole were subjected on gas chromatography instrument (HP Model 5890) equipped with $\mathrm{Ni}^{63}$ electron capture detector (ECD). An analytical column (30 $m$ length $\times 0.32 \mu \mathrm{mm}$ i.d. $\times 0.25 \mu \mathrm{m}$ film thickness) was used at temperature program as follows: injector $\left(280{ }^{\circ} \mathrm{C}\right)$, oven $\left(220^{\circ} \mathrm{C}\right.$ for $2 \mathrm{~min}$ and hold to $280{ }^{\circ} \mathrm{C}$ after $10 \mathrm{~min})$ and detector $\left(320{ }^{\circ} \mathrm{C}\right)$, respectively and Nitrogen was used as a carrier gas at flow rate $4 \mathrm{ml} / \mathrm{min}$.

Other examined compounds were exposed on High Performance Liquid Chromatography (HPLC) instrument (Agilent 1100 HPLC system, USA). The chromatographic used column was $\mathrm{C}_{18}$ Zorbax XDE $(250 \mathrm{~mm} \times 4.6 \mathrm{~mm}, 5 \mu \mathrm{m})$. The run was done at a flow rate 0.8 $\mathrm{ml} / \mathrm{min}$ of $\left(\mathrm{CH}_{3} \mathrm{CN}: \mathrm{H}_{2} \mathrm{O}, 65: 35 \mathrm{v} / \mathrm{v}\right)$ at room temperature Twenty $\mu \mathrm{l}$ of each analyte was responded on photodiode array detector at $220 \mathrm{~nm}$. All compounds were identified by their retention times compared to recognized standards.

\section{Quality assurance}

The methods were validated under the optimized conditions by determining limits of detection (LODs) and quantification (LOQs). The practical protocol was done according to published guide. All used solvents and reagents were in analytical grade. LOD of all compounds was $0.1 \mathrm{ng}$. On the other hand, recovery experiment for 'Quick Easy Cheap Effective Rugged and Safe' (QuEChERS) technique was done by spiking control samples with recognized amounts of the compounds and the procedures were done as described above. The mean value for all compounds was $98.0 \pm 3.0 \%$.

\section{Total carbohydrate quantification.}

The powder $(0.1 \mathrm{~g})$ of grains or straw was mixed with $4 \%$ of $\mathrm{NaOH}$ and boiled in water bath for $2 \mathrm{hr}$. After cooling, the samples were centrifuged at $\mathbf{3 0 0 0} \mathrm{rpm}$ for 10 minutes. An aliquot $(0.5 \mathrm{ml})$ was mixed with the same volume of phenol reagent $5 \%$ and $2.5 \mathrm{ml}$ of concentrated $\mathrm{H}_{2} \mathrm{SO}_{4}$ for $30 \mathrm{~min}$ at room temperature. The optical density was measured at wavelength $\mathbf{4 9 0}$ $\mathrm{nm}$ against blank on Spectronic 21D (Milton Roy Co. USA). Glucose was used as a standard to calculate the extension coefficient (Dubois et al. 1956) and expressed as \% of total weight.

\section{Total protein quantification}

Powder of samples (0.1 g) was extracted by $10 \mathrm{ml}$ of borate buffer (28.63 boric acid+ $29.8 \mathrm{~g} \mathrm{KCl}+3.5 \mathrm{~g} \mathrm{NaOH}$ in one liter of distilled water), kept overnight, then centrifuged at $\mathbf{3 0 0 0} \mathrm{rpm}$ for $\mathbf{1 0} \mathrm{min}$., filtered and completed to $\mathbf{1 0}$ $\mathrm{ml}$. Protein concentration was estimated according to (Lowry et al. 1951) and expressed as $\mathrm{mg} / \mathrm{g}$ dry weight.

\section{Data analysis}

Data was exposed to analysis of variance (ANOVA) and Least Significant Difference (LSD 0.05) was used to compare the means for all the variables within the experiment (Gomez and Gomez, 1984). 


\section{RESULTS AND DISCUSSION}

1. Assessment of disease and yield components

Stripe rust disease pressure was very high and excellent disease epidemic that developed to the level of creating significant difference among treatments across the two locations during the growing season.

Generally, results of tested fungicides are listed in Tables 1and 2 showing that all treatments reduced the severity of yellow rust and increased harvest yield. The level of disease severity was far higher in the untreated plots compared to treated ones. Application of Tilt ${ }^{\circledR} 25 \%$ EC at rate $0.1 \%$, recorded the minimum disease severity $(1.67 \%)$ compared with untreated plots $(86.67 \%)$. Grain yield exhibited increased percentages $29.92 \%$ and $73.61 \%$ in 1000 kernel weight compared with untreated ones. Crwan ${ }^{\circledR}$ $25 \%$ EC at rate $0.1 \%$ closely followed, by giving $94.61 \%$ control of stripe rust. It achieved increase values; 24.39 and $69.34 \%$ in grain yield and 1000 kernel weight, respectively. In addition, Fungshow $^{\otimes} 12.5 \%$ WP at rate $0.1 \%$, Meanar $^{\circledR} 41 \%$ EC at rate $0.1 \%$, Sumi- ${ }^{\circledR}$
$5 \% \mathrm{EC}$ at rate $0.1 \%$, Emnent ${ }^{\circledR} 12.5 \% \mathrm{EW}$ at rate $0.1 \%$, and Abatchi ${ }^{\circledR} 25 \%$ at rate $0.1 \%$ effectively reduced the stripe rust severity. These fungicides increased the grain yields with values; 25.63, 22.87, $18.31,14.92$, and $11.74 \%$ and reduced the disease severity with values; 96.91, 95.76, 95.38, 96.61and 94.61\%, respectively. Punch ${ }^{\circledR} 40 \%$ EC at rate $0.1 \%$ exhibited the least control values against stripe rust $93.85 \%$. Many investigators presented similar results. For example, Bal (2014), found that the application of Amistar $^{\circledR}$ fungicide, recorded the minimum disease severity compared with untreated plots. Viljanen-Rollinson et al. (2002), noted that the fungicide Azoxystrobin was very effective to reduce the rust diseases in wheat when applied as early eradicator. Bagga (2007), found that Amistar $^{\circledR}$ followed by Score ${ }^{\circledR}$ and Bayleton ${ }^{\circledR}$ significantly reduced the leaf rust severity resulting in improved grain yields and grain weight. Jorgensen and Nielsen (1994) reported that most of the ergosterol biosynthesis inhibiting (EBI) fungicides as triazoles gave 98$100 \%$ control of stripe rust.

Table 1. Effect of Different Fungicides on Yellow Rust Severity and Area Under Disease Progress Curve (AUDPC) of Tested Wheat Cultivar During 2017/2018 Growing Season.

\begin{tabular}{|c|c|c|c|c|c|c|}
\hline $\begin{array}{l}\text { Sr. } \\
\text { No. }\end{array}$ & Fungicide & Active ingredient & $\begin{array}{c}\text { Rate of } \\
\text { application }\end{array}$ & $\begin{array}{c}\text { Disease } \\
\text { severity (\%) }\end{array}$ & $\begin{array}{c}\text { Disease } \\
\text { control } \\
(\%)\end{array}$ & AUDPC \\
\hline 1 & Tilt $^{\circledR}$ 25\% EC & Propiconazole & $25 \mathrm{ml} / 100 \mathrm{l}$ & $1.67^{c} \pm 0.19$ & 98.07 & $16.33^{b} \pm 2.43$ \\
\hline 2 & $\begin{array}{l}\text { Crwan }^{\circledR} 25 \% \\
\text { EC }\end{array}$ & Propiconazole & 30 ml/100 l & $4.67^{b c} \pm 0.38$ & 94.61 & $50.17^{b} \pm 1.78$ \\
\hline 3 & $\begin{array}{l}\text { Fungshow }^{\circledR} \\
2.5 \% \text { WP }\end{array}$ & Diniconazole & $15 \mathrm{~g} / 100 \mathrm{I}$ & $2.67^{b c} \pm 0.19$ & 96.91 & $24.00^{b} \pm 2.91$ \\
\hline 4 & $\begin{array}{l}\text { Meanar }{ }^{\circledR} 41 \% \\
\text { EC }\end{array}$ & $\begin{array}{l}\text { Cyproconazole+ } \\
\text { Propiconazole }\end{array}$ & $200 \mathrm{ml} / 100 \mathrm{I}$ & $4.00^{b c} \pm 0.00$ & 95.76 & $40.83^{b} \pm 0.67$ \\
\hline 5 & Sumi-8 ${ }^{\circledR} 5 \%$ EC & Diniconazole & $35 \mathrm{ml} / 100 \mathrm{l}$ & $5.33^{b} \pm 0.38$ & 95.38 & $56.00^{\mathrm{b}} \pm 1.17$ \\
\hline 6 & $\begin{array}{l}\text { Emnent }{ }^{\circledR} 12.5 \% \\
\text { EW }\end{array}$ & Tetraconazole & $100 \mathrm{ml} / 100 \mathrm{I}$ & $2.67^{b c} \pm 0.19$ & 96.61 & $28.00^{b} \pm 2.33$ \\
\hline 7 & Abatchi ${ }^{\circledR} 25 \%$ & Propiconazole & $15 \mathrm{ml} / 100 \mathrm{I}$ & $4.67^{b c} \pm 0.38$ & 94.61 & $46.67^{b} \pm 1.35$ \\
\hline 8 & $\begin{array}{l}\text { Punch }^{\circledR} 40 \% \\
\text { EC } \\
\end{array}$ & Flusilazole & $19 \mathrm{ml} / 100 \mathrm{l}$ & $3.67^{b c} \pm 0.19$ & 93.85 & $36.17^{b} \pm 2.43$ \\
\hline 9 & $\begin{array}{l}\text { Untreated } \\
\text { control }\end{array}$ & --- & --- & $86.67^{\mathrm{a}} \pm 1.92$ & --- & $1131.67^{a} \pm 35.64$ \\
\hline
\end{tabular}

-Each value is the mean of three treated replicates \pm SE. No significant different at the same letters. Application of spray volume designed as 100l/feddan. 
Table 2. Effect of Different Fungicides on Yield Components of Tested Wheat Cultivar During 2017/2018 Growing Season.

\begin{tabular}{|c|c|c|c|c|c|c|}
\hline \multirow{2}{*}{$\begin{array}{l}\text { Sr. } \\
\text { No. }\end{array}$} & \multirow[b]{2}{*}{ Fungicide } & \multicolumn{5}{|c|}{ Mean of Yield Components } \\
\hline & & $\begin{array}{c}\text { 1000-Kernel } \\
\text { weight } \\
\text { (g) }\end{array}$ & $\begin{array}{c}\text { Increase } \\
\text { in 1000- } \\
\text { Kernel } \\
\text { weight } \\
(\%)\end{array}$ & $\begin{array}{c}\text { Grain yield } \\
\text { (Ardab/Feddan) }\end{array}$ & $\begin{array}{c}\text { Increase } \\
\text { in } \\
\text { Grain } \\
\text { Yield } \\
(\%) \\
\end{array}$ & $\begin{array}{c}\text { Straw yield } \\
\text { (Ton/Feddan) }\end{array}$ \\
\hline 1 & Tilt $^{\circledR}$ 25\% EC & $52.38^{\mathrm{a}} \pm 1.25$ & 73.61 & $18.80^{\mathrm{a}} \pm 0.52$ & 29.92 & $4.23^{\mathrm{ab}} \pm 0.16$ \\
\hline 2 & Crwan $^{\circledR} 25 \% E C$ & $51.09^{b} \pm 0.75$ & 69.34 & $18.00^{\mathrm{ab}} \pm 1.05$ & 24.39 & $4.13^{\mathrm{abc}} \pm 0.16$ \\
\hline 3 & $\begin{array}{l}\text { Fungshow }{ }^{\otimes} 12.5 \% \\
\text { WP }\end{array}$ & $46.71^{b} \pm 1.17$ & 54.82 & $18.18^{\mathrm{ab}} \pm 0.64$ & 25.63 & $4.00^{\mathrm{abc}} \pm 0.09$ \\
\hline 4 & Meanar $^{\circledR} 41 \%$ EC & $46.63^{b c} \pm 0.92$ & 54.55 & $17.78^{\mathrm{ab}} \pm 1.32$ & 22.87 & $3.89^{a b c} \pm 0.03$ \\
\hline 5 & Sumi $8^{\circledR} 5 \%$ WP & $45.17^{b c} \pm 0.62$ & 49.71 & $17.12^{\mathrm{ab}} \pm 0.85$ & 18.31 & $3.68^{\mathrm{bc}} \pm 0.21$ \\
\hline 6 & $\begin{array}{l}\text { Emnent }^{\circledR} 12.5 \% \\
\text { EW }\end{array}$ & $44.75^{c} \pm 0.24$ & 48.32 & $16.63^{\mathrm{ab}} \pm 0.19$ & 14.92 & $3.60^{c} \pm 0.07$ \\
\hline 7 & Abatchi $^{\circledR}(25 \%)$ & $42.48^{c} \pm 0.42$ & 40.80 & $16.17^{\mathrm{ab}} \pm 0.04$ & 11.74 & $3.53^{c} \pm 0.14$ \\
\hline 8 & Punch $^{\circledR}(40 \%)$ EC & $41.70^{d} \pm 0.35$ & 38.21 & $15.97^{\mathrm{ab}} \pm 0.77$ & 10.36 & $3.51^{\mathrm{cd}} \pm 0.09$ \\
\hline 9 & $\begin{array}{l}\text { Non- Protected } \\
\text { Control } \\
\end{array}$ & $30.17^{a} \pm 0.15$ & -- & $14.47^{c} \pm 0.05$ & --- & $2.92^{\mathrm{d}} \pm 0.01$ \\
\hline 10 & Protected control & $54.07^{b} \pm 1.06$ & 79.11 & $19.18^{a} \pm 0.07$ & 32.55 & $4.47^{a} \pm 0.05$ \\
\hline
\end{tabular}

-Each value is the mean of three treated replicates \pm SE. No significant different at the same letters.

Fungicide efficacy is depend on proper application timing to achieve optimum effectiveness of it as detected by labeled instructions and disease level in the field at the time of application. Kiersten (2016) reported that the differences in efficacy among fungicide products were detected by direct comparisons among products in field trials and are depend on a single application of the labeled rate. The popularity of spraying fungicides to control plant diseases; returns of up to three times the cost involved often were obtained from fungicide application (Ordish and Dufour 1969). Cook and King (1984) conducted experiments from 1978 to 1982 in the United Kingdom, and noted that applying pesticides to winter wheat resulted in a yield response of up to $89 \%$, and the value of increased yield from pesticide application to cereals in 1982 was nearly double the pesticide costs. Jørgensen et al. (2000) noted that the fungicide application to control wheat powdery mildew and Septoria diseases resulted in grain yield increases of 400 $2700 \mathrm{~kg} / \mathrm{ha}$ with margin of cost varying from $500 \mathrm{~kg} / \mathrm{ha}$ to $2000 \mathrm{~kg} / \mathrm{ha}$. Wegulo et al. (2009) noted that up to $42 \%$ yield loss was stopped by applying foliar fungicides to winter wheat. Kelley (2001) noted that for the period of six years, propiconazole fungicide significantly increased winter wheat yield up to $77 \%$. Vamshidhar et al. (1998) observed significant yield increases from fungicide usage against disease complex of leaf rust, tan spot, and Septoria tritici blotch in wheat. Ransom and McMullen (2008) noted that within an environment and across wheat varieties, fungicides promoted yields in range; 5.5 to $44.0 \%$. Milus (1994) reported that the application of tebuconazole and propiconazole at Zadoks growth stage (GS) 37 (Zadoks et al. 1974) followed by triadimefon + mancozeb at GS 55 against leaf rust and Septoria tritici blotch consistently 
resulted in low disease severities and high wheat yield.

\section{Residue levels.}

The residue levels of examined fungicides in grains and straw of wheat plants were determined after harvest. The residue levels in grains were greater than those in straw samples. Meanar ${ }^{\circledR}$ (cyproconzole) exhibited the greatest concentration in grain samples (2.201 $\mathrm{mg} / \mathrm{kg}$ ), but was found in below detection limit in straw samples. Eminent-treated plants exhibited the least concentration of tetraconazole $(0.016 \mathrm{mg} / \mathrm{kg})$ in grain samples and were below detection limits in straw samples. The residue levels of these compounds were as follows: Meanar $^{\circledR}>$ Tilt $^{\circledR}>$ Sumi ${ }^{\circledR}{ }^{\circledR}>$ Punche $^{\circledR}>$ Fungshow $^{\circledR}>\quad$ Abatchi $^{\circledR}>$. Other compounds did not exceed $0.036 \mathrm{mg} / \mathrm{kg}$. Fungshow $^{\circledR}$ and Punch $^{\circledR}$-treated plants exhibited concentrations in straw greater than those in grain samples accounting mean values of 0.653 and $0.705 \mathrm{mg} / \mathrm{kg}$, respectively. Sumi- ${ }^{\circledR}$ exhibited the mean value; $0.531 \mathrm{mg} / \mathrm{kg}$ in straw samples followed by Abatchi $^{\circledR}(0.289 \mathrm{mg} / \mathrm{kg})$. All examined fungicides exhibited concentration upper rough of EU permissible limits (European Commission), except tetraconazole which was found down MRL $(0.1 \mathrm{mg} / \mathrm{kg})$ (Table 3).

\section{Biochemical responses}

The examined compounds induced alterations in total carbohydrates and protein in grains and straw samples of treated plants (Table 4). In grain samples, Sumi-8 ${ }^{\circledR}$, Fungshow ${ }^{\circledR}$, Tilt $^{\circledR}$, Crown ${ }^{\circledR}$ and Abatch $^{\circledR}$ enhanced carbohydrates content to be greater than untreated group with mean values; 611.93, 619.65, $537.89,758.99$ and $599.30 \mathrm{mg} / \mathrm{g}$ mass, respectively. However, other compounds altered carbohydrates with mean values; 383.51, 376.79, and $298.6 \mathrm{mg} / \mathrm{g}$ mass for Punch $^{\circledR}$, Eminent ${ }^{\circledR}$ and Meaner $^{\circledR}$, respectively. In straw samples, all compounds altered carbohydrates content, except Eminent ${ }^{\circledR}$ and Meaner ${ }^{\circledR}$ induced an increase with values; 878.94 and $808.07 \mathrm{mg} / \mathrm{g}$ mass, respectively. Regarding total protein, all compounds induced an increase, except Fungshow ${ }^{\circledR}$ and Punch $^{\circledR}$ altered protein content with mean values; 9.49 and $10.55 \mathrm{mg} / \mathrm{g}$ mass compared with untreated plants (11.64 $\mathrm{mg} / \mathrm{g}$ mass). However, they altered protein content in straw samples, except Punch $^{\circledR}$ and Tilt ${ }^{\circledR}$ which increased protein levels to be 29.16 and $27.25 \mathrm{mg} / \mathrm{g}$ mass, respectively. Meaner ${ }^{\circledR}$ and Abatchi $^{\circledR}$ induced the least level (13.87 $\mathrm{mg} / \mathrm{g}$ mass) compared with untreated group (21.89 $\mathrm{mg} / \mathrm{g}$ mass).

Table 3. Fungicide Residues ( $\mathrm{mg} / \mathrm{kg}$ ) in Grains and Straw of Treated Wheat.

\begin{tabular}{|c|c|c|c|c|c|}
\hline \multirow{2}{*}{$\begin{array}{l}\text { Sr. } \\
\text { No. }\end{array}$} & \multirow[t]{2}{*}{ Fungicide } & \multirow{2}{*}{$\begin{array}{c}\text { Active } \\
\text { ingredient }\end{array}$} & \multicolumn{2}{|c|}{ Residues (mg/kg) } & \multirow{2}{*}{$\begin{array}{c}{ }^{*} \mathrm{MRL} \\
(\mathrm{mg} / \mathrm{kg}\end{array}$} \\
\hline & & & Grains & Straw & \\
\hline 1 & Sumi-8 ${ }^{\circledR}$ & Diniconazole & $0.630 \pm 0.053$ & $0.531 \pm 0.060$ & 0.01 \\
\hline 2 & Fungshow $^{\circledR}$ & Diniconazole & $0.436 \pm 0.004$ & $0.653 \pm 0.037$ & 0.01 \\
\hline 3 & Tilt $^{\circledR}$ & Propinconazole & $0.987 \pm 0.043$ & $0.708 \pm 0.062$ & 0.02 \\
\hline 4 & Crown $^{\circledR}$ & Propinconazole & $0.030 \pm 0.000$ & $0.033 \pm 0.005$ & 0.02 \\
\hline 5 & Meaner $^{\circledR}$ & Propinconazole & $0.036 \pm 0.001$ & $0.015 \pm 0.005$ & 0.02 \\
\hline 6 & Abatchi $^{\circledR}$ & Propinconazole & $0.280 \pm 0.003$ & $0.289 \pm 0.004$ & 0.02 \\
\hline 7 & Punch $^{\circledR}$ & Flusilazole & $0.573 \pm 0.079$ & $0.705 \pm 0.058$ & 0.01 \\
\hline 8 & Eminent $^{\circledR}$ & Tetraconazole & $0.016 \pm 0.010$ & BDL & 0.1 \\
\hline 9 & Meaner $^{\circledR}$ & Cyproconzole & $2.201 \pm 0.029$ & BDL & 0.1 \\
\hline & LSD 5\% & - & 0.615 & 0.487 & - \\
\hline
\end{tabular}

- "MRL= maximum residue limits; setting by EU pesticides database and BDL=below detection limit 
Table 4. Total Carbohydrates and Protein in Treated Wheat.

\begin{tabular}{|c|c|c|c|c|c|}
\hline \multirow[t]{2}{*}{$\begin{array}{l}\text { Sr. } \\
\text { No. }\end{array}$} & \multirow[t]{2}{*}{ Fungicide } & \multicolumn{2}{|c|}{$\begin{array}{l}\text { Total carbohydrates } \\
\text { (mg/g mass) }\end{array}$} & \multicolumn{2}{|c|}{$\begin{array}{l}\text { Total protein } \\
\text { (mg/g mass) }\end{array}$} \\
\hline & & Grains & Straw & Grains & Straw \\
\hline 1 & Sumi $8^{\circledR}$ & $611.93^{c} \pm 0.08$ & $583.51^{c d} \pm 0.14$ & $12.37^{\text {cde }} \pm 0.15$ & $17.99^{\mathrm{d}} \pm 0.05$ \\
\hline 2 & Fungshow $^{\circledR}$ & $619.65^{c} \pm 0.08$ & $776.14^{a b} \pm 0.13$ & $9.49^{e} \pm 0.20$ & $15.16^{e} \pm 0.09$ \\
\hline 3 & Tilt $^{\circledR}$ & $537.89^{c} \pm 0.09$ & $769.12^{\mathrm{ab}} \pm 0.14$ & $12.98^{\mathrm{cd}} \pm 0.14$ & $27.25^{a} \pm 0.05$ \\
\hline 4 & Punch $^{\circledR}$ & $383.51^{d e} \pm 0.13$ & $671.39^{b c} \pm 0.16$ & $10.55^{d e} \pm 0.18$ & $29.16^{a} \pm 0.05$ \\
\hline 5 & Eminent $^{\circledR}$ & $376.79^{d e} \pm 0.13$ & $878.94^{a} \pm 0.12$ & $16.65^{\mathrm{ab}} \pm 0.11$ & $19.14^{\mathrm{cd}} \pm 0.07$ \\
\hline 6 & Crwan $^{\circledR}$ & $758.99^{b} \pm 0.07$ & $722.96^{b c} \pm 0.14$ & $12.36^{\mathrm{cde}} \pm 0.15$ & $21.05^{b c} \pm 0.06$ \\
\hline 7 & Meaner $^{\circledR}$ & $298.60^{c} \pm 0.17$ & $808.07^{a b} \pm 0.13$ & $14.13^{b c} \pm 0.13$ & $13.87^{e} \pm 0.10$ \\
\hline 8 & Abatchi $^{\circledR}$ & $599.30^{c} \pm 0.08$ & $464.49^{d} \pm 0.23$ & $17.20^{\mathrm{ab}} \pm 0.11$ & $13.87^{e} \pm 0.10$ \\
\hline 9 & Untreated control & $423.16^{\mathrm{de}} \pm 0.12$ & $774.03^{a b} \pm 0.14$ & $11.64^{\text {cde }} \pm 0.16$ & $21.89^{b c} \pm 0.06$ \\
\hline
\end{tabular}

Many investigations relied that most of triazole fungicides decreased growth parameters of crops. For example, tebuconazole decreased seed protein content of Legumes (Ahmed 2011). Other investigations (Guttieri et al. 2001; Ceseviciene and Masauskiene 2008; Triboi et al. 2003; Souza et al. 2004) noted that fungicide efficacy on grain quality based firstly on weather conditions being conductive to the occurrence of fungal diseases and then on fungicide applied. Kelley (2001) found that, fungicides help to keep vegetation of the leaves allowing conditions for larger grains growth and get better quality. Gaurilcikiene et al. (2010) reported that the protein levels in harvest grain of fungicide-treated plants were $138 \mathrm{~g} / \mathrm{kg}$ and $136 \mathrm{~g} / \mathrm{kg}$ for Rombus ${ }^{\circledR}$ (trifloxystrobin + propiconazole) and Opera $^{\circledR} \quad$ (pyroclostrobin + epoxyconazole), respectively. However, Tilt $^{\circledR}$ treatment exhibited $144 \mathrm{~g} / \mathrm{kg}$.

\section{Conclusions}

The results of this study revealed that the use of fungicides e.g. Tilt ${ }^{\circledR} 25 \% \mathrm{EC}$, Crwan $^{\circledR} 25 \%$ EC, Fungshow ${ }^{\circledR} 12.5 \%$ WP, Meanar $^{\circledR} \quad 41 \%$ EC, Sumi-8 ${ }^{\circledR} 5 \%$ EC, Eminent $^{\circledR} 12.5 \% \mathrm{EW}$, Abatchi ${ }^{\circledR} 25 \%$ and Punch $^{\circledR}$ 40\% EC reduced yellow rust disease severity to the lowest level possible and revealed grain yield advantage better than the untreated application so that these fungicides included within management strategies. Furthermore, there is a need to continuously monitor the crop during the growing season so that maximum benefits can be achieved by applying the fungicides at appropriate time. In the end we would like to take attention about fungicides residues and their effect on human and wildlife.

\section{REFERENCES}

Afzal, S. N., M. I. Haque, M. S. Ahmedani, S. Bashir and A R. Rattu (2007). Assessment of yield losses caused by Puccinia striiformis triggering stripe rust in the most common wheat varieties. Pakistan Journal of Botany, 39: 2127-2134.

Ahmed, M. (2011). A comparative analysis of Tebuconazole mediated phytotoxicity to Legumes. Journal of Environmental Science and Technology, 4(6): 630-637.

Bagga, P. S. (2007). Efficacy of triazole and strobilurin fungicides for controlling Fusarium Head Blight and Brown rust of wheat in Punjab. Indian Phytopathology, 60(4): 489-493. 
Bal, R. S. (2014). Effect of some fungicides and time of fungicidal spray on stripe rust of wheat. Journal of Plant and Pest Science, 1(1): 39-43.

Ceseviciene, J. and A. Masauskiene (2008). The effect of harvest time on winter wheat grain protein content and sedimentation index. ZemdirbysteAgriculture, 95(1): 58-72.

Chen, X. M. (2005). Epidemiology and control of stripe rust (Puccinia striiformis $f \mathrm{sp}$. tritici) on wheat. Canadian Journal of Plant Pathology, 27, 314-337.

Chen, X.M. (2007). Challenges and solutions for stripe rust control in the United States. Australian Journal of Agricultural Research, 58: 648-655.

Cook, R. J. and J. E. King (1984). Loss caused by cereal diseases and the economics of fungicidal control, Plant Diseases: Infection, Damage and Loss, Blackwell, pp. 237-245, ISBN 0632011262, Oxford, UK.

Dubois, M., K. A. Gilles, J. K. Hamilton, P. A. Rebers and S. Smith (1956). Colorimetric method for determination of sugars and related substances. Analytical Chemistry, 28: 350-356.

FAO. (2009). Wheat Flour. Food and Agriculture Organization of the United Nations, FAO Agribusiness hand book. Rome, Italy. Available at www.eastagri.org.

Gaurilcikiene, I., B. Butkute and A. Mankeviciene (2010). A multi-aspect comparative investigation on the use of strobilurin and triazole-based fungicides for winter wheat disease control. Fungicides Odile Carisse (Ed.), ISBN: 978-953-307-266. 1. In Tech

http://www.intechopen.com/books/fun gicides/.

Gebril, E. E. M. A., M. A. Gad and A. M. S. Kishk (2018). Effect of sowing dates on potential yield and rust resistance of some wheat cultivars. J. Plant
Production, Mansoura Univ., 9 (4): 369 $-375$.

Gomez, K. A. and K. H. Gomez (1984). Statistical Procedures for Agricultural Research (2 ${ }^{\text {nd }}$ Edition). New York: John Willy and Sans Press.

Guttieri, M. J., J. C. Stark, K. M. O'Brien and E. Souza (2001). Relative sensitivity of spring wheat grain yield and quality parameters to moisture deficit. Crop Science, 41(2): 327-335.

Hasan, M. A., O. A. Boult, M. Abou-Zeid and $M$ A. Gad (2016). Impact of different levels of stem and stripe rust severities on two grain yield components of wheat. Minufiya $\mathrm{J}$. of Agric. Res., 41 (3): 621-629.

Jiang, Y., X. Li, J. Xu, C. Pan, J. Zhang and W. Niu (2009). Multiresidue method for the determination of 77 pesticides in wine using QuChERs sample preparation and gas chromatography with mass spectrometry. Food Additive Contaminants, 26: 859-866.

Jorgensen, L. N. and B. J. Nielsen (1994). Control of yellow rust (Puccinia striiformis) on winter wheat by ergosterol inhibitors at full and reduced dosages. Crop Protection, 13(5): 323-330.

Jørgensen, L. N., K. E. Henriksen and G C. Nielsen (2000). Margin over cost in disease management in winter wheat and spring barley in Denmark, Brighton Crop Protection Conference: Pests \& Diseases-2000: Volume 2: Proceedings of an International Conference, pp. 655-662, ISBN 1901396-59-2, Brighton, UK, November 13-16, 2000.

Kelley, K. W. (2001). Planting date and foliar fungicide effects on yield components and grain traits of winter wheat. Agronomy Journal, 93(2): 380389, ISSN 0002-1962.

Kiersten, W. (2016). Fungicide Efficacy for Control of Wheat Diseases. Purdue 
Extension Education Store. Purdue University. Available at www.edustore.purdue.edu.

Line, R F. (2002). Stripe rust of wheat and barley in North America: a retrospective historical review. Annual Review of Phytopathology, 40, 75-118.

Lowry, O. H., N. J. Rasebrough, A. L. Farr and R. J. Randall (1951). Protein measurement with the folin phenol reagent. Journal Biological Chemistry, 193: 265-275.

Milus, E. A. (1994). Effect of foliar fungicides on disease control, yield and test weight of soft red winter wheat. Crop Protection, 13(4): 291-295 ISSN 0261-2194.

Murray, G. M., P. J. Ellison and A. Watson (1995). Effects of stripe rust on the wheat plant. Australasian Plant Pathology, 24: 261-270.

Ordish, G. and D. Dufour (1969). Economic bases for protection against plant diseases. Annual Review of Phytopathology, 7(1): 31-50, ISSN 0066-4286.

Peterson, R. F., A. B. Campbell, A. E. Hannah (1948). A diagrammatic scale for rust intensity on leaves and stems of cereals. Canadian Journal of Research, 26: 496-500.

Ransom, J. K. and M P. McMullen (2008). Yield and disease control on hard winter wheat cultivars with foliar fungicides. Agronomy Journal, 100(4): 1130-1137, ISSN 0002-1962.

Russell, P. E. (2005). A century of fungicide evolution. Journal of Agricultural Sciences, 143, 11-25.

Shewry, P. R. (2009). Wheat. Journal of Experimental Botany, 60: 1537-1553.
Souza, E. J., J. M. Martin and M J. Guttieri (2004). Influence of genotype, environment, and nitrogen management on spring wheat quality. Crop Science, 44(2), 425-432.

Triboi, E., P. Martre and A M. TriboiBlondel (2003). Environmentallyinduced changes in protein composition in developing grains of wheat are related to changes in total protein content. Journal of Experimental Botany, 54(358): 17311742.

USDA. (2010). World Agricultural Production. United States Department of Agriculture, Washington DC, USA.

Vamshidhar, P., T. J. Herrman, W. W. Bockus and T. M. Loughin (1998). Quality response of twelve hard red winter wheat cultivars to foliar disease across four locations in central Kansas. Cereal Chemistry, 75 (1): 9499, ISSN 0009-0352.

Viljanen-Rollinson, S. L. H., R. A. Parkes, T. Armour and M G. Cromey (2002). Fungicide control of stripe rust in wheat: Protection or eradication? New Zealand Plant Protection, 55: 336-340.

Wegulo, S. N., J. A. Breathnach and P. S. Baenziger (2009). Effect of growth stage on the relationship between tan spot and spot blotch severity and yield in winter wheat. Crop Protection, 28 (8): 696-702, ISSN 0261-2194.

Weise, M. V. (1987). Compendium of wheat diseases. $2^{\text {nd }}$ Edition APS Press, The American Phytopathological Society, St Paul MN, USA, pp112.

Zadoks, J. C., T. T. Chang and C. F. Konazak (1974). A decimal code for growth stages of cereals. Weed Research, 14: 415-421. 


\section{تقييم الكفاءة الابادية لبعض المبيدات الفطرية ضد مرض الصدا الاصفر في القمح وبعض التغييرات البيوكيماويـة}

محمد عبد الله ابوالعنين جاد(')، خالد ياسين عبدالحليم(؟)، فايزة احمد صديق(؟)،

هانم محمود سليمان(r)

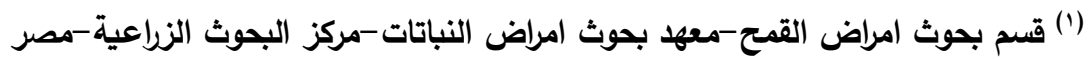

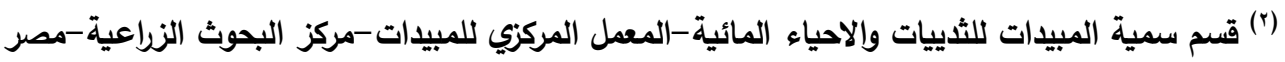

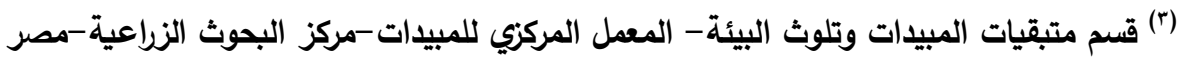

الملخص العربي

الصداء الاصفر في القمح يسببه فطر P. striiformis ويعتبر من الامراض المدمرة لمحصول القدح وهو منتشر في

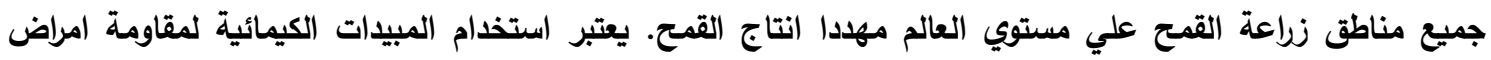

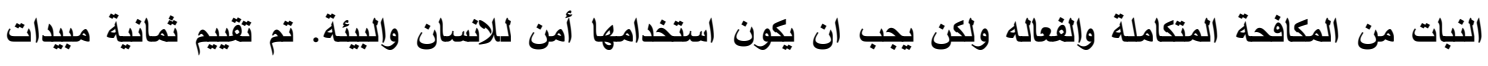

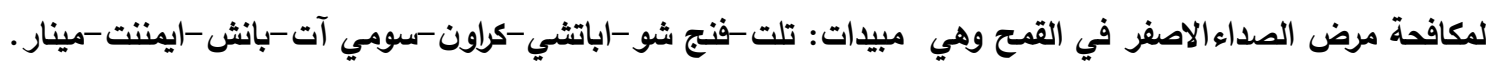
تم تقدير متبقي هذه المركبات في كلا من الحبوب والتبن بعد الحصاد. وقد نفذت هذه التجربه في موقدين التهين مختلفين خلال

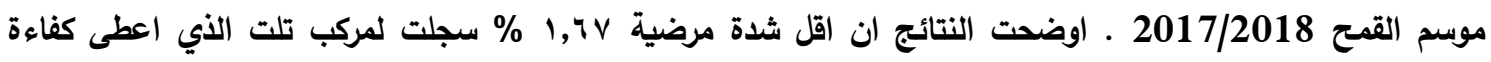

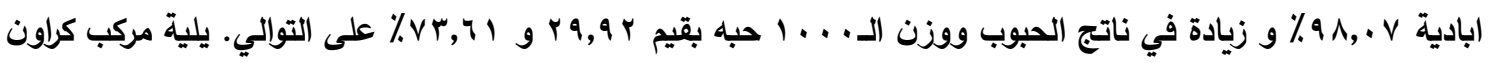

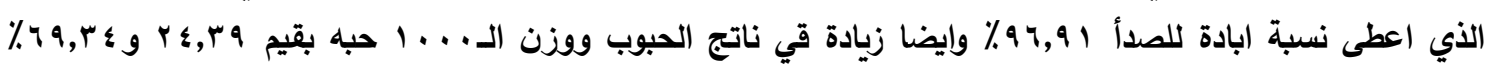

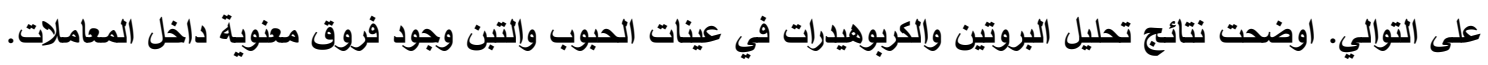

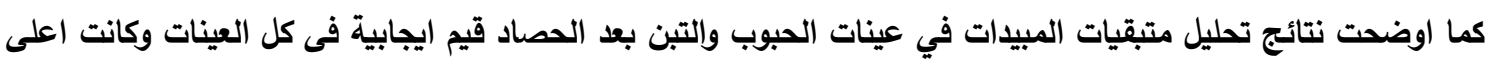

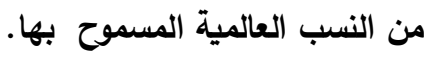

